\title{
Microsatellite instability in Marek's Disease Virus infected primary chicken embryo fibroblasts
}

\author{
Zhenlei Zhou, Dawei Yao, Yan Qiu and Deji Yang ${ }^{*}$
}

\begin{abstract}
Background: Marek's disease virus (MDV), an oncogenic a-herpes virus, causes a devastating disease in chickens characterized by development of lymphoblastoid tumors in multiple organs. Microsatellite instability (MSI), a symptom of defect in DNA mismatch repair function, is a form of genomic instability frequently detected in many types of tumors. However, the involvement of MSI in MDV-infected cells has not been investigated. In this study, we determined the presence and frequency of MSI in primary chicken embryo fibroblasts infected with or without MDV strain in vitro.

Results: 118 distinct microsatellite markers were analyzed by polymerase chain reaction (PCR) in 21 samples. MSI was found in 91 of 118 markers, and 12 out of 118 demonstrated frequency of MSI at $\geq 40 \%$. 27 of 118 microsatellite loci did not show microsatellite instability.

Conclusions: These findings showed that MSI was a real event occurring in primary chicken embryo fibroblasts infected with MDV in vitro as evidenced by the high frequency of MSI, and may be specifically associated with genome alteration of host cells during MDV infected.
\end{abstract}

Keywords: Microsatellite instability, Marek's disease virus, Chicken embryo fibroblasts

\section{Background}

Marek's disease (MD), caused by the highly oncogenic lymphotropic Marek's disease virus (MDV), is a highly contagious neoplastic disease of poultry. MD is characterized by lymphomas and lymphoproliferative infiltration of their visceral organs, peripheral nerves, muscles and skin [1]. Although many different kinds of control measures have been implemented against the disease since 1907, MD remains a severe threat to poultry industry in many countries because of its high occurrence. Economically losses from MD is estimated at least US $\$ 1$ billion annually [2].

The pathogenesis of MD is complex and is not fully understood. Susceptible genotypes of birds are infected by the infectious virus which replicates in the host lymphoid organs. B-cells and macrophages undergo a lytic infection, resulting in the activation of T-cells. The latent $\mathrm{T}$-cells become targets for neoplastic transformation leading to the development of lymphomatous tumors in various visceral organs $[3,4]$. Some of the

\footnotetext{
* Correspondence: yangdeji63@sohu.com

College of Veterinary Medicine, Nanjing Agricultural University, Nanjing, Jiangsu 210095, P.R. China
}

factors that lead to MD lymphomas have been investigated. A study demonstrated that MDV might induce host cell DNA strand breaks. Accumulation of genomic alteration over time can lead to gene modifications in cells that might turn to be mutagenic or carcinogenic [5].

Genetic mutations may occur throughout the genome, involving gross chromosomal aberrations or only variations in the length of genomic DNA fragments carrying microsatellite sequences. Microsatellites are repetitive DNA sequences comprised of short reiterative motifs, which locates within the heterochromatin near chromosomal centromeres and telomeres [6]. Microsatellite sequences are stably inherited with high accuracy making them excellent genetic markers. The length of microsatellite sequences is unique to each individual and distinct among individuals. In addition, individual has identical microsatellite in different kinds of cells. Microsatellite mutations or microsatellite instability (MSI) leads to DNA replication error (RER) phenotype. If uncorrected, these errors are fixed after a next round of replication as addition or deletion of one or more microsatellite sequences. This mutated phenotype manifests as 
MSI, and appears to play an important role in tumorigenesis and/or tumor progression [7-9].

Marek's disease provides excellent model for the study of herpes virus-induced tumors both in experimental and natural conditions. Therefore the main objective of the present study was to determine the presence and frequency of MSI in chicken fibroblasts infected with the Marek's disease virus, and to determine microsatellites markers with high frequency of MSI for prediction of host cells gene alteration by virus in vitro.

\section{Results}

A total of 21 samples were determined for the presence of MIS. All samples were tested at 118 microsatellite loci. Alternations in the size of microsatellites in the MDVinfected samples were revealed as differences in the electrophoretic migration of MDV-infected DNA as compared with control DNA. The MSI frequencies of MDV-infected chicken embryo fibroblasts are summarized in Table 1 and representative samples are illustrated in Figure 1. Twelve markers showed high frequency of MSI (>40\%). These markers were ABR0052, ABR0392, LEI0099, ABR0123, ADL0199, ABR0007, ABR204, ABR0086, ABR0059, ABR0634, ABR0133 and ABR0026. 27 microsatellite markers showed no change in length of fragments and 79 microsatellite markers had the lower occurrence of MSI (<40\%). Over all, the incidence of MSI in CEF samples of 21 chicken embryos induced by the virus was $100 \%$, at least one microsatellite marker was demonstrated MSI (data not showed).

\section{Discussion}

Marek's disease is a very common disease and provides excellent model for the study of herpes virus-induced tumors in both experimental and natural conditions. In this study, chicken embryo fibroblasts were used to evaluate the effects of MDV on host cells genome in vitro. It was reported that not only lymphocytes but also primary chicken embryo fibroblasts could be targets for neoplastic transformation by the MDV [10]. Microsatellite instability (MSI), reflecting a cellular deficiency in DNA mismatch repair (MMR), is now regarded as an important biomarker to predict the cellular genome mutation.

Microsatellites are located in both non-coding and coding portions of the genome, and are thought to play a functional role in gene regulation or indirectly as hot spots for recombination. MSI phenotype mainly caused by mutations in the DNA mismatch repair (MMR) genes. This defect may alter gene expression and contribute to cancer development and progression by accelerating the accumulation of mutations in tumor-related genes [11]. MSI in human tumors development and progression has been extensively investigated, which was regarded to have a closed relationship with malignancies, such as endometrial, renal, colorectal, and gastric cancer [12-15]. The present study indicates for the first time an association between MSI and MDV infection. It was showed that the high frequency of MSI in MDV-infected CEF specimens could be regarded as one of the fundamental feature of CEF transformation. Regulation from oncogenic genes derived from MDV could be a major driving force of the transformation [10]. It is envisaged MDV might lead to defect of MMR system during replication in host cells, which may result in dysregulation of cell division, imbalance between cell growth and death, and act as a trigger for the initiation of cell transformation.

\section{Conclusions}

In conclusion, this study demonstrates that MSI is presented and its frequency is high in MDV infection in vitro, and MSI may be related to pathogenesis of MDV disease. In order to identify whether the hypothesis is true, we are investigating and comparing MSI frequency of microsatellites markers in chickens infected with pathogenic strain or the non-pathogenic strains (e.g. CVI988). More studies were still needed to further to determine predictive microsatellite markers and evaluate whether MSI is a useful independent prognosticator.

\section{Methods}

\section{Chicken embryo fibroblasts (CEF) and Marek's disease} virus infection

Twenty-one chicken embryos (9-days old) from SPF eggs for preparation of chicken embryo fibroblast (CEF) were from SPAFAS Co. (Jinan, China; a joint venture with Charles River Laboratory, Wilmington, MA, USA). Each embryos was trypsinized according to conventional procedures, and the cells were suspended in Medium 199 supplemented with $5 \%$ calf serum, glutamine $(2 \mathrm{mM})$, sodium pyruvate $(1 \mathrm{mM})$, Penicillin $(1000 \mathrm{u} / \mathrm{mL})$ and Streptomycin $(1000 \mu \mathrm{g} / \mathrm{ml})$ in a $75 \mathrm{~cm}^{2}$ flask (Corning Glass Works, Coming, NY). The fibroblasts from each chicken embryo were divided into two for in vitro culture. One is assigned for control and another for infection with the virulent RB-1B strain of MDV. The RB-1B strain of MDV was provided by Dr. Aijian Qin (College of Veterinary Medicine, Yangzhou University, China).

\section{DNA extraction}

At day 5 post infection of MDV, 95\% of CEF showed cytopathic effect (CPE). The control fibroblasts and MDV-infected CEFs were used for DNA exraction. The cells were scraped from the flasks and pelleted by centrifugation. The pellet was washed once with $0.2 \mathrm{~mol} / \mathrm{L} \mathrm{pH}$ 7.2 phosphate buffered saline and pelleted again. The pellet was lysed in digestion buffer $(10 \mathrm{mM}$ Tris-Cl $\mathrm{pH}$ 8.0, 0.1 M EDTA pH 8.0, 0.5\% SDS, $20 \mu \mathrm{g} / \mathrm{mL}$ pancreatic RNase) and treated with proteinase $\mathrm{K}$. After extraction 
Table 1 MSI frequencies of samples from chicken embryo fibroblasts infected by Marek's disease virus

\begin{tabular}{|c|c|c|c|c|c|}
\hline Markers & NO. of samples & Frequency & Markers & NO. of samples & Frequency \\
\hline MCW0248 & $2,6,11,13,15,17,18,21$ & $8 / 21(38.01 \%)$ & MCW0134 & $3,4,6,7,9,10,20,21$ & $8 / 21(38.10 \%)$ \\
\hline ABR0352 & $1,3,6,8,12,19,20$ & 7/21(33.33\%) & ABR0325 & $4,10,11,14,17,19,20$ & 7/21(33.33\%) \\
\hline ABR0329 & $5,10,11,12,14,17,18$ & $7 / 21(33.33 \%)$ & MCW0067 & $2,3,4,8,10,12,14,15$ & 8/21(38.10\%) \\
\hline LEI0209 & None & 0 & ABR0495 & $3,10,15,17,18,19,20$ & 7/21(33.33\%) \\
\hline ABR0528 & $3,7,14,16,18$ & $5 / 21(23.81 \%)$ & ADL0038 & $10,12,13,16,18,20$ & $6 / 21(28.57 \%)$ \\
\hline ABR0139 & $3,7,17$ & $3 / 21(14.29 \%)$ & ADL0106 & $2,9,10,16,18,21$ & 6/21(28.57\%) \\
\hline ABR0007 & $2,5,6,7,8,9,10,17,18$ & $9 / 21(42.86 \%)$ & ADL0112 & None & 0 \\
\hline ABR0379 & $6,9,11,14,15$ & $5 / 21(23.81 \%)$ & ABR0478 & None & 0 \\
\hline ABR0518 & $1,2,6$ & $3 / 21(14.29 \%)$ & ADL0123 & None & 0 \\
\hline LEI0146 & $5,6,7,11,16,18,20$ & 7/21(33.33\%) & ABR0052 & $2,4,6,7,9,10,11,14,16,17,19,20$ & $12 / 21(57.14 \%)$ \\
\hline ABR0525 & $9,11,12$ & $3 / 21(14.29 \%)$ & ABR0389 & $6,8,11,12,14,17,21$ & 7/21(33.33\%) \\
\hline ABR0594 & $4,9,15,21$ & $4 / 21(19.05 \%)$ & ADL0308 & $1,4,7,10,12,13,14$ & $7 / 21(33.33 \%)$ \\
\hline ABR0280 & None & 0 & ABR0037 & $6,11,15,18,19$ & $5 / 21(23.81 \%)$ \\
\hline ABR0542 & $4,5,6,7,15$ & 4/21(19.05\%) & ABR0059 & $1,4,7,10,11,12,14,16,21$ & 9/21(42.83\%) \\
\hline ABR0117 & $1,3,4,9,12,21$ & $6 / 21(28.57 \%)$ & ABR0033 & $2,3,7,9,11,14,16,18$ & $8 / 21(38.10 \%)$ \\
\hline ADL0150 & None & 0 & ABR0634 & $1,2,3,6,9,10,11,14,19$ & 9/21(42.83\%) \\
\hline ABR0368 & None & 0 & ABR0086 & $1,3,4,6,12,13,14,18,21$ & 9/21(42.83\%) \\
\hline ABR0521 & $4,9,11,14,17,19$ & $6 / 21(28.57 \%)$ & LEI0099 & $2,3,4,7,8,9,11,13,14,16,18,21$ & $12 / 21(57.14 \%)$ \\
\hline MCW0058 & $4,5,6,8,9,10$ & $6 / 21(28.57 \%)$ & ABR0271 & $1,2,6,16,20$ & 5/21(23.81\%) \\
\hline ABR0522 & $1,6,9,13,19,20,21$ & 7/21(33.33\%) & ABR0506 & None & 0 \\
\hline ABR0373 & None & 0 & ADL0147 & $1,2,3,6,9,10,14,21$ & 8/21(38.10\%) \\
\hline ABR0172 & None & 0 & MCW0322 & None & 0 \\
\hline ABR0504 & None & 0 & ADL0225 & $6,11,14,15$ & 4/21(19.05\%) \\
\hline ADL0268 & 8 & $1 / 21(4.76 \%)$ & ABR0365 & $1,6,9,11,14,19,20$ & 7/21(33.33\%) \\
\hline MCW0327 & None & 0 & ABR0517 & $3,4,5,9,10,12,21$ & 7/21(33.33\%) \\
\hline ABR0247 & $3,4,10,14$ & $4 / 21(19.05 \%)$ & ABR0530 & $1,2,6,13,18$ & $5 / 21(23.81 \%)$ \\
\hline ABR0185 & $1,3,10$ & $3 / 21(14.29 \%)$ & ABR0257 & None & 0 \\
\hline ABR0609 & None & 0 & ADL0293 & $2,7,9,12,19$ & 5/21(23.81\%) \\
\hline MCW0200 & None & 0 & MCW0330 & $1,3,4,8,14$ & $5 / 21(23.81 \%)$ \\
\hline ABR0204 & $2,6,7,10,13,14,15,18,21$ & 9/21(42.86\%) & ABR0387 & $1,6,8,10,15,17,19$ & 7/21(33.33\%) \\
\hline ABR0649 & $1,3,10,15$ & 4/21(19.05\%) & ADL0199 & $1,2,3,8,9,13,14,17,18,21$ & 10/21(47.62\%) \\
\hline MCW0036 & $2,6,10,19$ & 4/21(19.05\%) & ABR0374 & $3,9,11,14$ & 4/21(19.05\%) \\
\hline ABR0169 & None & 0 & MCW0217 & $7,8,11,15,16,17$ & $6 / 21(28.57 \%)$ \\
\hline ABR0284 & $4,8,12,13,17,19,20$ & 7/21(33.33\%) & ABR0650 & $2,6,7,11,14,16,19$ & 7/21(33.33\%) \\
\hline ABR0113 & $1,2,6,10,12,16$ & $6 / 21(28.57 \%)$ & MCW0094 & None & 0 \\
\hline MCW0167 & None & 0 & ABR0133 & $1,3,5,6,8,13,18,19,20$ & 9/21(42.86\%) \\
\hline LEI0106 & $4,7,12,17,21$ & $5 / 21(23.81 \%)$ & ABR0180 & $6,7,9,12,13,16,19$ & 7/21(33.33\%) \\
\hline LEI0168 & None & 0 & MCW0304 & $8,10,15,19$ & 4/21(19.05\%) \\
\hline MCW0145 & $3,5,8,9,10,13,15,17$ & $8 / 21(38.10 \%)$ & ABR0364 & None & 0 \\
\hline ABR0549 & $4,5,7,8,14,16$ & $6 / 21(28.57 \%)$ & ABR0223 & $3,18,19,20$ & 4/21(19.05\%) \\
\hline ABR0424 & $2,6,13,18,21$ & $5 / 21(23.81 \%)$ & ABR0001 & $7,8,10,11,14,21$ & 6/21(28.57\%) \\
\hline LEI0162 & 16 & $1 / 21(4.76 \%)$ & ABR0123 & $2,5,6,7,8,9,10,11,14,18$ & $10 / 21(47.62 \%)$ \\
\hline ADL0198 & None & 0 & ABR0026 & $1,5,6,9,13,14,15,18,21$ & 9/21(42.85\%) \\
\hline ABR0287 & $4,5,7,8,14,18,19$ & 7/21(33.33\%) & ABR0405 & $2,4,5,6,7,19$ & 6/21(28.57\%) \\
\hline
\end{tabular}


Table $1 \mathrm{MSI}$ frequencies of samples from chicken embryo fibroblasts infected by Marek's disease virus (Continued)

\begin{tabular}{llllll}
\hline ABR0641 & None & 0 & ABR0624 & $5,7,15,20$ & $4 / 21(19.05 \%)$ \\
ABR0631 & $5,6,10,12,18$ & $5 / 21(23.81 \%)$ & LEI0102 & 9 & $1 / 21(4.76 \%)$ \\
MCW0115 & $4,7,9,10,11,13,14,20$ & $8 / 21(38.10 \%)$ & ADL0262 & 17 & $1 / 21(4.76 \%)$ \\
ABR0609 & None & 0 & MCW0301 & $6,15,19,21$ & $4 / 21(19.05 \%)$ \\
ABR0140 & $7,8,11,18,20$ & $5 / 21(23.81 \%)$ & ROS0302 & $3,10,13,15,20$ & $5 / 21(23.81 \%)$ \\
ABR0392 & $2,3,4,5,6,7,8,10,12,15,16,20$ & $12 / 21(57.14 \%)$ & MCW0262 & $1,5,6,11,17$ & $5 / 21(23.81 \%)$ \\
ABR0046 & 6 & $1 / 21(4.76 \%)$ & ABR0109 & $9,11,18$ & $3 / 21(14.29 \%)$ \\
ABR0391 & $1,3,9,10,17,21$ & $6 / 21(28.57 \%)$ & ABR0617 & $1,6,7,8,9,15,16$ & $7 / 21(33.33 \%)$ \\
ADL0253 & $8,11,18$, & $3 / 21(14.29 \%)$ & MCW0069 & $8,9,20$ & $3 / 21(14.29 \%)$ \\
ADL0292 & $10,19,20$ & $3 / 21(14.29 \%)$ & ABRO006 & $1,2,3,9,10,18$ & $6 / 21(28.57 \%)$ \\
MCW0214 & 4,21 & $2 / 21(9.52 \%)$ & ABR0015 & None & 0 \\
ABR0299 & $11,4,5,6,16$ & $5 / 21(23.81 \%)$ & ABR0076 & $4,9,13,16$ & $4 / 21(19.05)$ \\
LEI0130 & None & 0 & LEI0135 & $5,19,20$ & $3 / 21(14.29 \%)$ \\
ABR0526 & $4,7,8,10,16,18,20$ & ADL0254 & None & 0 \\
ABR0362 & $1,4,7,8,14,18$ & ABR0066 & 12,20 & $2 / 21(9.52 \%)$ \\
\hline
\end{tabular}

with phenol, DNA was precipitated with ethanol, dissolved in $1 \mathrm{X}$ TE (10 mM Tris-Cl pH 7.5, $1 \mathrm{mM}$ EDTA). The concentration of DNA was determined by $\mathrm{OD}_{260}$ using the BioPhotometer plus (Eppendorf, Germany). The quality of DNA was checked by agarose gel electrophoresis.

\section{Primers, PCR and gel electrophoresis}

One-hundred-eighteen microsatellite markers in chicken linkage map [16] were chosen to determine MSI in present study (Table 1). Each microsatellite repeat was amplified by polymerase chain reaction (PCR) and subjected to gel electrophoresis aimed at comparing the pattern of MDV-infected DNA and control DNA from the same chicken embryo fibroblasts. All primers were provided by Dr. Takahashi, National Institute of Agro biological Sciences (NIAS), Tsukuba, Japan.

PCR was performed in a $12.5 \mu \mathrm{L}$ reaction mixture containing $0.5 \mu$ l template DNA (100 ng), $0.5 \mu \mathrm{l}$ of Taq
DNA polymerase $(2.5 \mathrm{U} / \mu \mathrm{l}), 1.25 \mu \mathrm{l}$ of $10 \times$ PCR buffer, $0.5 \mu \mathrm{l}$ of each primer $(5 \mu \mathrm{mol} / \mathrm{L}), 1 \mu \mathrm{l}$ of dNTPs ( $2.5 \mathrm{mmol} / \mathrm{L}$ ), $8.25 \mu \mathrm{l}$ distilled $\mathrm{H}_{2} \mathrm{O}$. PCR was performed as following steps: a hot start, $94^{\circ} \mathrm{C}$ for $15 \mathrm{~s}$, then $94^{\circ} \mathrm{C}$ for $15 \mathrm{~s}, 55^{\circ} \mathrm{C}$ for $30 \mathrm{~s}$, and $68^{\circ} \mathrm{C}$ for $60 \mathrm{~s}$, all repeated for 10 cycles, followed by 10 under the same condition except for the annealing temperature that was changed to $50^{\circ} \mathrm{C}$ and $45^{\circ} \mathrm{C}$, finally an elongation time of $9 \mathrm{~min}$ at $68^{\circ} \mathrm{C}$. PCR amplification was performed using the PTC200 (Bio-Rad, USA). PCR products were separated by electrophoresis in $12 \%$ polyacrylamide gel containing $6 \mathrm{M}$ urea for $2.5 \mathrm{~h}$ at $70 \mathrm{~W}$. Gels were fixed in $10 \%$ acetic acid, and stained with $\mathrm{AgNO}_{3}$ [17].

\section{Microsatellite analysis}

Each gel was compared with matched normal and MDV-infected CEF specimens. To accurately size the PCR products, a DNA ladder was used on both sides of the gel. Comparisons were made between the number of

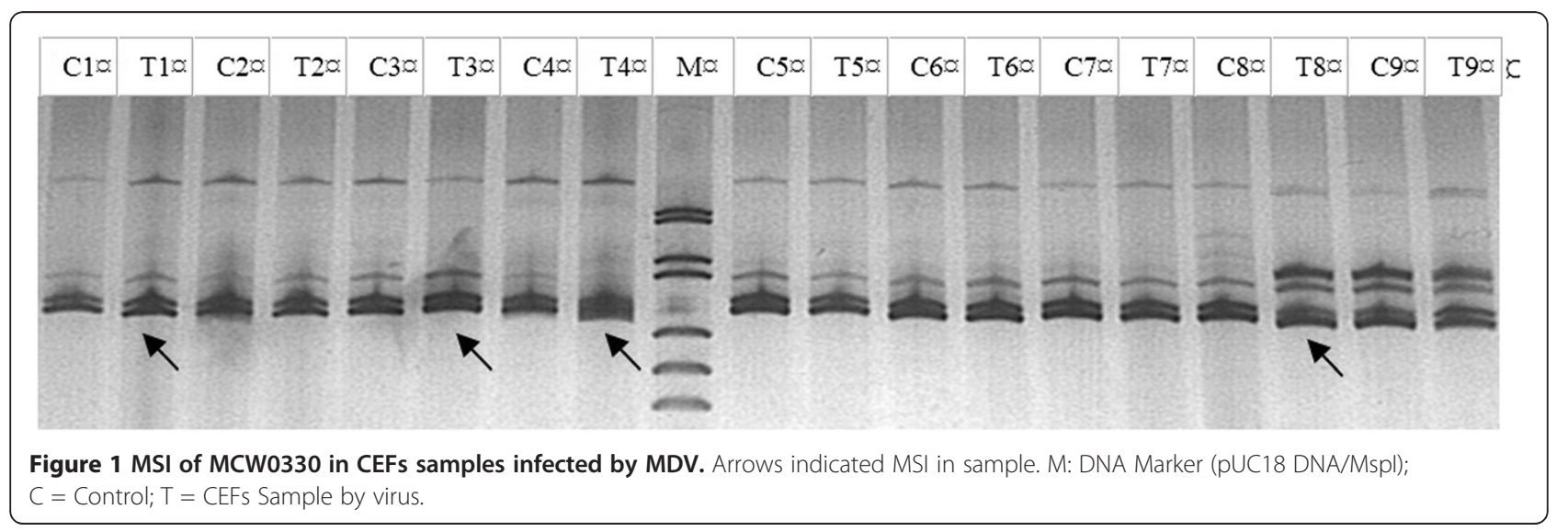


bands present in both MDV-infected and normal CEF samples. Band intensity was noted but was not categorized for differences between the normal and abnormal DNA. To quantify the presence or absence of MSI, each primer was analyzed for differences in the number of alleles present, be it through insertions or deletions (Figure 1). All microsatellite markers were analyzed for each MDV-infected CEF sample. If the number of allelic bands were not equal in number, band intensity had a significant difference, they were graded as MSI.

\section{Competing interests}

The authors declare that they have no competing interests.

\section{Authors' contributions}

DJY designed research. ZLZ carried out most of the studies, interpreted the data and drafted the manuscript. DWY and QY participated in parts of the studies and writing. All authors read and approved the final manuscript.

\section{Acknowledgements}

The research was supported by National Nature Science Foundation of China (NO.30871847) and A Project Funded by the Priority Academic Program Development of Jiangsu Higher Education Institutions (PAPD).

Received: 15 September 2011 Accepted: 31 August 2012

Published: 11 September 2012

\section{References}

1. Saif YM, Barnes HJ: Diseases of poultry. Ames, lowa: Blackwell Pub. Professional; 2008:452-514. 12.

2. Nair V: Evolution of Marek's disease - A paradigm for incessant race between the pathogen and the host. Vet J 2005, 170:175-183.

3. Wakenell PS, O'Connell P, Blackmore C, Mondal SP, Schat KA: Role of Marek's disease herpes virus in the induction of tumours in Japanese quail (Coturnix coturnix japonica) by methylcholanthrene. Avian Pathol 2010, 39:183-188.

4. Schat KA, Markowski-Grimsrud CJ: Immune responses to Marek's disease virus infection. Curr Top Microbiol Immunol 2001, 255:91-120

5. Keles H, Fidan AF, Cigerci IH, Kucukkurt I, Karadas E, Dundar Y: Increased DNA damage and oxidative stress in chickens with natural Marek's disease. Vet Immunol Immunopathol 2010, 133:51-58.

6. Atkin NB: Microsatellite instability. Cytogenet Cell Genet 2001, 92:177-181.

7. Woerner SM, Kloor M, von Knebel Doeberitz M, Gebert JF: Microsatellite instability in the development of DNA mismatch repair deficient tumors. Cancer Biomark 2006, 2:69-86.

8. Vaish M, Mittal B: DNA mismatch repair, microsatellite instability and cancer. Indian J Exp Biol 2002, 40:989-994.

9. Vasavi M, Kiran V, Ravishankar B, Prabhakar B, Ahuja YR, Hasan Q Microsatellite instability analysis and its correlation with hMLH1 repair gene hypermethylation status in esophageal pathologies including cancers. Cancer Biomark 2010, 7:1-10.

10. Buranathai C, Rodriguez J, Grose C: Transformation of primary chick embryo fibroblasts by Marek's disease virus. Virology 1997, 239:20-35.

11. Shah SN, Hile SE, Eckert KA: Defective mismatch repair, microsatellite mutation bias, and variability in clinical cancer phenotypes. Cancer Res 2010, 70:431-435.

12. Corso G, Velho S, Paredes J, Pedrazzani C, Martins D, Milanezi F, Pascale V, Vindigni C, Pinheiro H, Leite M, Marrelli D, Sousa S, Carneiro F, Oliveira C, Roviello F, Seruca R: Oncogenic mutations in gastric cancer with microsatellite instability. Eur I Cancer 2011, 47:443-451.

13. Tinelli A, Mezzolla V, Leo G, Pisanò M, Storelli F, Alemanno G, Malvasi A, Tommasi S, Ronzino G, Lorusso V: Microsatellite instability (MSI) as genomic markers in endometrial cancer: toward scientific evidences. Mini Rev Med Chem 2010, 10:1356-1365.

14. Altavilla G, Fassan M, Busatto G, Orsolan M, Giacomelli L: Microsatellite instability and hMLH1 and hMSH2 expression in renal tumors. Oncol Rep 2010, 24:927-932.
15. de la Chapelle A, Hampel $\mathrm{H}$ : Clinical relevance of microsatellite instability in colorectal cancer. J Clin Oncol 2010, 28:3380-3387.

16. Takahashi H, Tsudzuki M, Sasaki O, Niikura J, Inoue-Murayama M, Minezawa M: A chicken linkage map based on microsatellite markers genotyped on a Japanese Large Game and White Leghorn cross. Anim Genet 2005, 36:463-467.

17. Bassam BJ, Caetano-Anolles G, Gresshoff PM: Fast taxand sensitive silver staining of DNA in polyacrylamide gels. Anal Biochem 1991, 196:80-83.

doi:10.1186/1743-422X-9-193

Cite this article as: Zhou et al:: Microsatellite instability in Marek's Disease Virus infected primary chicken embryo fibroblasts. Virology Journal 2012 9:193.

\section{Submit your next manuscript to BioMed Central and take full advantage of:}

- Convenient online submission

- Thorough peer review

- No space constraints or color figure charges

- Immediate publication on acceptance

- Inclusion in PubMed, CAS, Scopus and Google Scholar

- Research which is freely available for redistribution 